\title{
Sea urchin fecal production and accumulation in a rocky subtidal ecosystem
}

\author{
Leah K. Sauchyn ${ }^{1, *}$, Jean-Sébastien Lauzon-Guay ${ }^{2}$, Robert E. Scheibling ${ }^{1}$ \\ ${ }^{1}$ Biology Department, Dalhousie University, Halifax, Nova Scotia B3H 4J1, Canada \\ ${ }^{2}$ Institut Maurice-Lamontagne, Fisheries and Oceans Canada, Mont-Joli, Québec G5H 3Z4, Canada
}

\begin{abstract}
We used a spatial model of destructive grazing of kelp beds by dense aggregations (fronts) of sea urchins Strongylocentrotus droebachiensis, together with measures of sea urchin absorption efficiency and fecal degradation rate, to predict rates of fecal production and accumulation during the transition from a kelp bed to a barrens state in a rocky subtidal ecosystem of Nova Scotia, Canada. The rate of fecal production as dry mass reached $9.17 \mathrm{~g} \mathrm{~m}^{-2} \mathrm{~d}^{-1}$ at $10 \mathrm{yr}$ after the formation of a grazing front, with associated rates of carbon and nitrogen production of $2.12 \mathrm{~g}$ $\mathrm{C} \mathrm{m}^{-2} \mathrm{~d}^{-1}$ and $0.21 \mathrm{~g} \mathrm{~N} \mathrm{~m}^{-2} \mathrm{~d}^{-1}$. Fecal production rate exceeded the rates of physical, chemical, and microbial degradation, such that up to $193.6 \mathrm{~g}$ of feces, $70.2 \mathrm{~g}$ of $\mathrm{C}$, and $4.0 \mathrm{~g}$ of $\mathrm{N}$ accumulated per linear $\mathrm{m}$ of front after $10 \mathrm{yr}$. The extent of sea urchin grazing fronts along the Atlantic coast of Nova Scotia was estimated at $280 \mathrm{~km}$ in 2000 , which translates to a total fecal production rate of $6423 \mathrm{~kg}$ of feces d $\mathrm{d}^{-1}$ and an accumulation of $54200 \mathrm{~kg}$ of feces after $10 \mathrm{yr}$ of front formation, based on our model. This temporally variable flux of organic matter likely has a profound effect on adjacent deeper-water macrobenthic communities utilizing the feces as a food source.
\end{abstract}

KEY WORDS: Fecal production - Organic matter flux - Degradation - Kelp bed - Sea urchin . Strongylocentrotus droebachiensis

\section{INTRODUCTION}

Kelp beds or forests form extensive biogenic habitats in temperate coastal regions and are among the most productive ecosystems in the ocean (Mann 2000). While kelp beds are relatively resilient to disturbance, they are periodically decimated by thermal fluctuations, storms, and herbivore outbreaks (Dayton et al. 1998, Steneck et al. 2002). Large-scale destructive grazing of kelp beds by sea urchins can cause a shift to an alternative community state-corallinedominated barrens (Lawrence 1975, Uthicke et al. 2009).

In the Northwest Atlantic, the sea urchin Strongylocentrotus droebachiensis plays a pivotal role in determining community structure in the rocky subtidal zone (Scheibling \& Hatcher 2007). At high densities (up to 500 ind. $\mathrm{m}^{-2}$ ), sea urchins form grazing aggregations (fronts) along the lower margins of kelp beds, driving the transition to barrens (Scheibling et al. 1999, Lauzon-Guay \& Scheibling 2007). These grazing fronts, which can extend from 100s of meters to kilometres alongshore (Miller \& Nolan 2000), consume large quantities of kelp (up to $1 \mathrm{~kg}$ (m front) ) $^{-1}$ $\mathrm{d}^{-1}$; Scheibling et al. 1999, Lauzon-Guay \& Scheibling 2007). Estimates of sea urchin absorption efficiency suggest that 30 to $50 \%$ of this material is defecated as globular, mucus-covered fecal pellets that are 1 to $3 \mathrm{~mm}$ in diameter (Miller \& Mann 1973, Larson et al. 1980, Sauchyn \& Scheibling 2009a). These fecal pellets are transported by waves and currents and deposited in sedimentary habitats in deeper waters (Sauchyn \& Scheibling 2009a). Thus, defecation by sea urchins may represent a significant path of detrital export from the kelp bed ecosystem.

Feces are an important source of organic matter for the microbial community, stimulating the growth of attached and free-living bacteria and protozoa 
(Povero et al. 2003, Thor et al. 2003). In turn, microbes increase the nutritional value of the feces by contributing to the labile organic matter fraction (González \& Biddanda 1990, Fabiano et al. 1994) through remineralization of dissolved organic matter (Urban-Rich 1999, Povero et al. 2003) and uptake of dissolved inorganic nutrients from the water column (Wotton \& Malmqvist 2001, Povero et al. 2003). Microbial degradation of sea urchin feces leads to an increase in the available energy content and a decrease in the fecal C:N ratio (Sauchyn \& Scheibling 2009b), suggesting that the degraded feces are an important food source for suspension and deposit feeding invertebrates in the rocky subtidal zone and in adjacent sedimentary habitats in deeper water (Newell 1965, Frankenberg \& Smith 1967, Lopez \& Levinton 1987). While fecal production and biodeposition have been well studied in suspension feeding invertebrates such as bivalves (Haven \& MoralesAlamo 1966, Kautsky \& Evans 1987, Fabiano et al. 1994, Norling \& Kautsky 2007, 2008), the role of sea urchins and other benthic grazers in these processes remains poorly understood (Mamelona \& Pelletier 2005, Sauchyn \& Scheibling 2009a,b).

In this paper, we combined a spatial population dynamics model of destructive grazing of kelp by Strongylocentrotus droebachiensis (Lauzon-Guay et al. 2009) with estimates of absorption efficiency and fecal degradation rate to predict fecal production by sea urchins during the transition from kelp bed to urchin barrens states. This modelling exercise allowed us to further explore the ecological consequences of state shifts in a rocky subtidal ecosystem of Nova Scotia, in terms of material and energy flow via grazing and detrital pathways.

\section{MATERIALS AND METHODS}

\section{Model description}

We used the model developed by Lauzon-Guay et al. (2009) to calculate the amount of kelp Saccharina longicruris consumed by a grazing front of sea urchins Strongylocentrotus droebachiensis after urchin mass mortality. The model tracks sea urchin density and kelp biomass over a 1-dimensional domain extending from the surviving sea urchin population (at $>20 \mathrm{~m}$ depth) to the shore. The only site-specific parameter is bathymetry, which determines the offshore distance between the surviving urchin population and the remaining kelp bed $(<8 \mathrm{~m}$ depth, in wave exposed habitats). The sea urchin population was modelled using a size-structured integro-difference equation (Neubert \& Caswell 2000), with sizespecific survival and growth, and habitat-specific (barrens, front, kelp bed) growth and recruitment. The initial biomass of algae between the kelp bed and the deeper, surviving population of sea urchins after mass mortality was assumed to be $50 \mathrm{~g} \mathrm{~m}^{-2}$, and re-establishment of the kelp bed was modelled using Ricker's model of growth (Turchin 2003) with an added term for grazing, and assuming large dispersal distances for kelp (Gaylord et al. 2004). The model assumes that sea urchins move in random directions in the absence of kelp and remain stationary when kelp is present. The model also assumes that sea urchins can only forage on erect macroalgae when feeding in groups, and above a threshold ratio of urchin to kelp biomass (0.5). Initial conditions and parameter estimates were obtained from the literature and detailed descriptions of the model structure and parameter estimates are provided by LauzonGuay et al. $(2008,2009)$. Previous work has described the reformation and subsequent advance of a sea urchin feeding front following a mass mortality, in terms of both the density of urchins within the front and the rate of advance of the front over time (Lauzon-Guay et al. 2009).

In the present study, we describe changes over time in the amount of kelp consumed by an urchin front and the resultant fecal material made available in the system after physical, chemical, and microbial degradation. We used simulation results corresponding to the reformation of a feeding front and its expected propagation over a period of $10 \mathrm{yr}$ at a site (Splitnose Point) near Halifax, Nova Scotia following the last mortality event which occurred there in September 1999 (Lauzon-Guay \& Scheibling 2007, Lauzon-Guay et al. 2009). While the sea urchin grazing model is spatially explicit and sea urchins move within the system, we did not account for resuspension or horizontal advection of fecal material once it has been deposited by sea urchins. Therefore, fecal material was assumed to remain where it was produced by sea urchins within the front. Although this does not allow us to determine where the feces will accumulate, it enables prediction of the flux of fecal pellets that can be incorporated into energy budgets.

\section{Fecal production}

The mass of feces produced $\left(W_{t}(x)\right)$ at time $t$ (days) at position $x$ (in $\mathrm{m}$ ) was calculated by multiplying the dry weight of kelp eaten $\left(k_{t}(x)\right)$ by the absorption effi- 
ciency (as dry weight) of sea urchins feeding on kelp $\left(\alpha_{k}, 64.8 \% \pm 3.0 \mathrm{SE}\right.$; Sauchyn \& Scheibling 2009a):

$$
W_{t}(x)=\left(1-\alpha_{k}\right) k_{t}(x)
$$

The dry weight of kelp eaten was obtained by multiplying the total mass of kelp consumed by sea urchins (obtained from the model output) by a wet to dry weight conversion factor of $0.159( \pm 0.011 \mathrm{SE})$ for Saccharina longicruris (Sauchyn \& Scheibling 2009a).

\section{Fecal degradation}

Degradation of feces through time was modelled by Sauchyn \& Scheibling (2009b) using an exponential decay function:

$$
F_{d}=0.682 e^{-0.411 d}+0.317
$$

where $F_{d}$ is the proportion of feces (as dry weight) remaining $d$ days after they were produced. Similarly, the proportions of organic carbon and nitrogen remaining as feces were modelled as:

$$
C_{d}=0.090 \mathrm{e}^{-0.601 d}+0.142
$$

and

$$
N_{d}=0.015 e^{-935.166 d}+0.008
$$

where $C_{d}$ and $N_{d}$ are respectively the proportions of the initial dry weight of feces that remain as organic carbon and nitrogen, $d$ days after the feces were produced. Eqs. (3) \& (4) evaluated at $d=0$ represent the production of organic carbon and nitrogen, respectively. We did not differentiate between carbon and nitrogen originating from the feces from those originating from attached bacteria. Therefore, our estimates represent the total organic carbon and nitrogen present in the feces and likely underestimate the actual degradation rates. Measurements used to estimate fecal production and degradation rates were obtained from field experiments conducted at Splitnose Point and from laboratory experiments with sea urchins and kelp collected from this site (Sauchyn \& Scheibling 2009a,b). Feces used to determine in situ degradation rates were maintained in containers covered with $63 \mu \mathrm{m}$ mesh for $19 \mathrm{~d}$. This mesh size allowed exchange of bacteria and most Protozoa with the surrounding sea water, but excluded larger metazoans. Therefore, losses of fecal mass, organic carbon, and nitrogen were due to microbial degradation and physical and chemical processes. Field experiments indicate that depth (from 6 to $16 \mathrm{~m}$ ) and temperature (from 4 to $18^{\circ} \mathrm{C}$ across depth and time) have no significant effects on degradation of sea urchin feces
(Sauchyn \& Scheibling 2009b); therefore, the same equations were used to estimate fecal degradation at all positions $X$.

\section{Feces available}

The total mass of fecal material $\left(T F_{t}(x)\right)$ at some position $x$ at time $t$ is the sum of the remaining feces produced per linear $\mathrm{m}$ of urchin front over the previous $19 \mathrm{~d}$, calculated as:

$$
T F_{t}(x)=\sum_{d=0}^{19} F_{d} W_{t-d}(x)
$$

Similarly, the total mass of organic carbon $\left(T C_{t}(x)\right)$ and nitrogen $\left(T N_{t}(x)\right)$ in fecal material at position $x$ at time $t$, produced per linear $\mathrm{m}$ of urchin front over the previous $19 \mathrm{~d}$, are respectively:

and

$$
T C_{t}(x)=\sum_{d=0}^{19} C_{d} W_{t-d}(x)
$$

$$
T N_{t}(x)=\sum_{d=0}^{19} N_{d} W_{t-d}(x)
$$

The $19 \mathrm{~d}$ interval was based on the duration of the in situ degradation experiment. After 19 d, $70 \%$ of the total mass of fecal material had been lost (Sauchyn \& Scheibling 2009b). While our model was run over $10 \mathrm{yr}$, we did not track feces and nutrients over the entire span of our simulation. At any one location, feces were tracked for $19 \mathrm{~d}$, after which they were assumed to have been fully degraded.

\section{Elasticity analysis}

We conducted an elasticity analysis on the total production of feces over $10 \mathrm{yr}$. We calculated the proportional change in biomass of feces produced by a $1 \mathrm{~m}$ wide section of the front in response to a $10 \%$ increase in several parameters of the model (for urchins: movement, growth survival, recruitment, grazing; for kelp: carrying capacity, growth).

\section{RESULTS}

At the start of our simulation, kelp started to grow down to the upper limit of the surviving sea urchin population $(20 \mathrm{~m}$ depth), where a grazing front formed and advanced to $5 \mathrm{~m}$ depth within $10 \mathrm{yr}$ (Fig. 1). Over this period, fecal production (dry weight) increased from 0.95 to $22.94 \mathrm{~g}$ ( $\mathrm{m}$ front $)^{-1} \mathrm{~d}^{-1}$ as kelp consumption increased due to an increase 
in urchin density from 13.1 to 129.4 ind. $\mathrm{m}^{-2}$ within the grazing front (Fig. 2a). The production of organic carbon and nitrogen increased concomitantly from 0.22 to $5.32 \mathrm{~g} \mathrm{C}$ (m front $)^{-1} \mathrm{~d}^{-1}$ and from 0.02 to $0.52 \mathrm{~g}$ $\mathrm{N}$ (m front) ${ }^{-1} \mathrm{~d}^{-1}$ (Fig. 2b). For a $2.5 \mathrm{~m}$ wide front

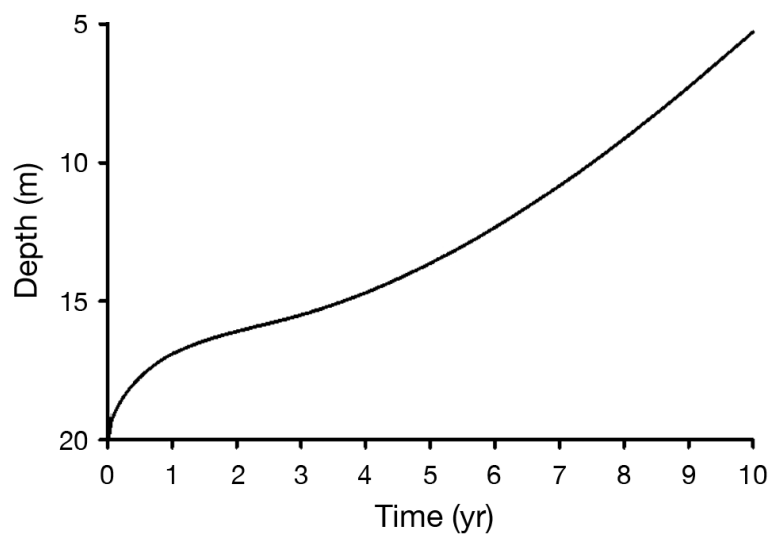

Fig. 1. Stongylocentrorus droebachiensis. Predicted depth of sea urchin front over time at Splitnose Point, Nova Scotia, over a $10 \mathrm{yr}$ period following mass mortality of sea urchins
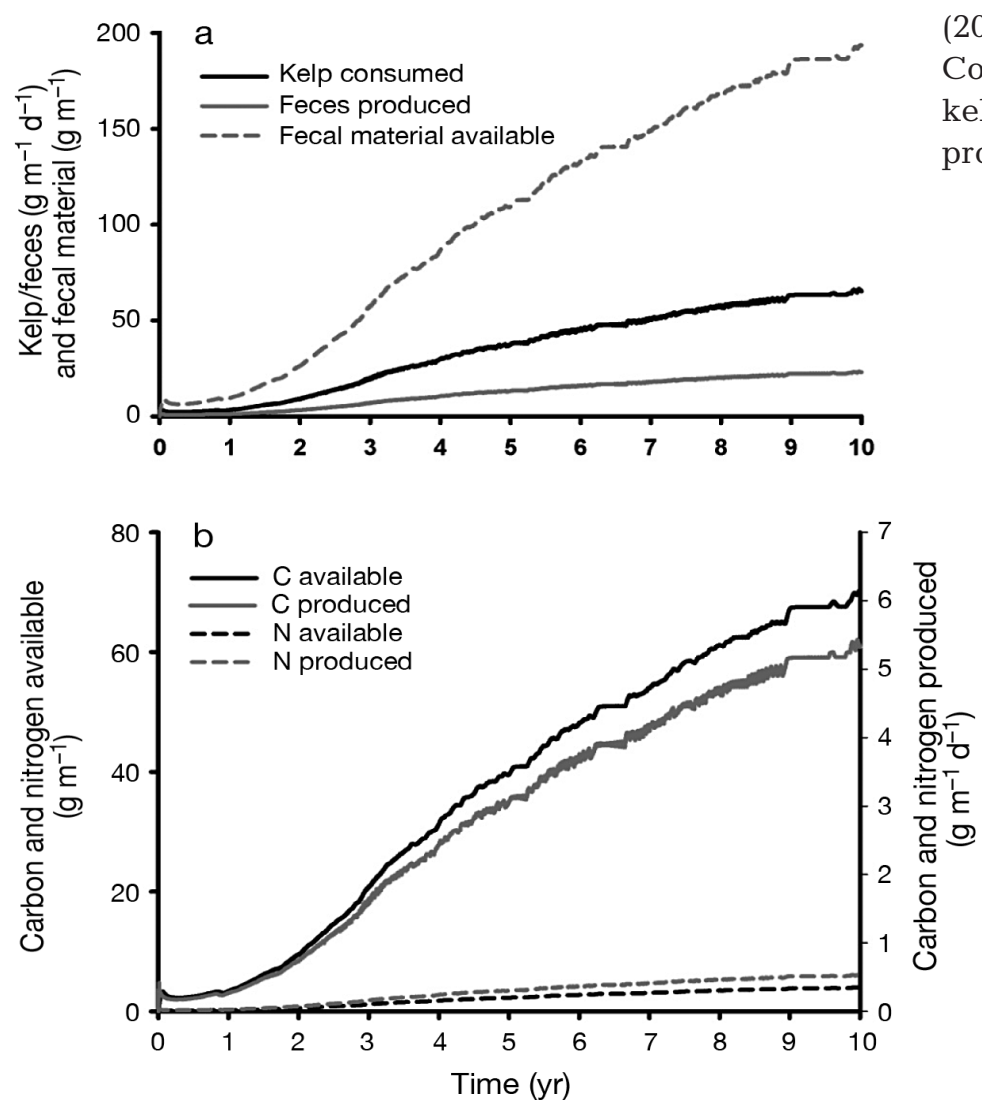

Fig. 2. Strongylocentrotus droebachiensis. (a) Kelp consumed, fecal material produced, and fecal material available per linear $\mathrm{m}$ of sea urchin front over time. (b) Organic carbon and nitrogen in the fecal material produced and available per linear $\mathrm{m}$ of front over time
(Lauzon-Guay \& Scheibling 2007) with 129 urchins $\mathrm{m}^{-2}$, our model predicted a fecal production rate of $9.17 \mathrm{~g} \mathrm{~m}^{-2} \mathrm{~d}^{-1}$ and associated carbon and nitrogen production rates of $2.12 \mathrm{~g} \mathrm{C} \mathrm{m}^{-2} \mathrm{~d}^{-1}$ and $0.21 \mathrm{~g} \mathrm{~N} \mathrm{~m}^{-2}$ $\mathrm{d}^{-1}$, at $10 \mathrm{yr}$.

The rate of fecal production exceeded that of physical, chemical, and microbial degradation, such that the mass of feces produced per linear $\mathrm{m}$ of front accumulated behind the advancing front, up to $193.55 \mathrm{~g}$ dry weight over a $19 \mathrm{~d}$ period at $10 \mathrm{yr}$ after front formation (Figs. 2a \& 3). The concomitant accumulation of organic carbon and nitrogen in the feces over $19 \mathrm{~d}$ was $70.22 \mathrm{~g}$ $\mathrm{C}$ and $4.01 \mathrm{~g} \mathrm{~N}$ at $10 \mathrm{yr}$ (Figs. 2b \& 3). We did not include dispersal of feces in our model. Therefore, the patterns of accumulation of fecal mass, organic carbon, and nitrogen in our model followed that of kelp consumption and fecal production, and were maximal at the interface of the kelp bed and urchin barrens (Fig. 3).

Total fecal production rate over the $10 \mathrm{yr}$ following a mass mortality of urchins, was most sensitive to an increase in parameters affecting the sea urchin population (Fig. 4). Specifically, fecal production was most sensitive to an increase in urchin survival $(20.6 \%)$, movement $(10.3 \%)$ and growth $(7.1 \%)$. Conversely, increases in parameters pertaining to kelp dynamics had relatively small effects on the production of feces $(<5 \%)$.

\section{DISCUSSION}

\section{Feces production}

In the rocky subtidal zone of Nova Scotia, marked changes in the production and export of particulate matter as sea urchin feces occur on a decadal time scale, following major transitions in ecosystem state (Scheibling et al. 1999, LauzonGuay et al. 2009). As grazing fronts advance and sea urchins transform kelp beds into corallinedominated urchin barrens, vast amounts of feces are produced (Sauchyn \& Scheibling 2009a). During this transition, the rates of destructive grazing and fecal production increase over time due to an increase in sea urchin density at the front (Lauzon-Guay et al. 2009). According to our model, fecal production per linear $\mathrm{m}$ of front increases to $9.17 \mathrm{~g} \mathrm{~m}^{-2} \mathrm{~d}^{-1}$ after $10 \mathrm{yr}$, with carbon and nitrogen production rates of $2.12 \mathrm{~g} \mathrm{C} \mathrm{m}^{-2} \mathrm{~d}^{-1}$ and $0.21 \mathrm{~g} \mathrm{~N} \mathrm{~m}^{-2} \mathrm{~d}^{-1}$. These fecal production rates are higher than those estimated by Mamelona \& Pelletier (2005) for a front of Strongylocentrotus droebachiensis feeding on the kelp Alaria 


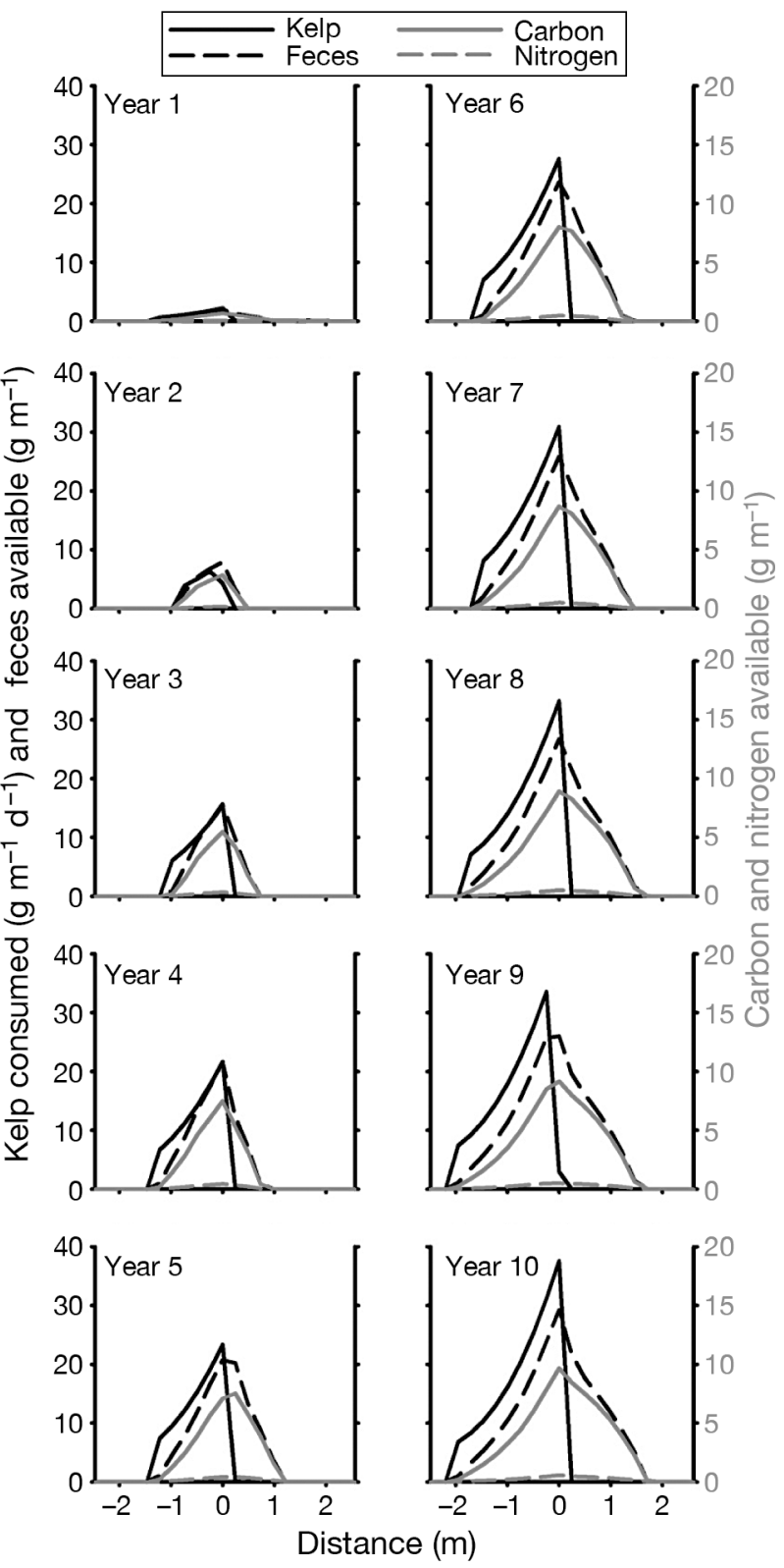

Fig. 3. Strongylocentrotus droebachiensis. Kelp consumed, and fecal mass, organic carbon, and nitrogen available at the sea urchin grazing front at 1 to $10 \mathrm{yr}$ after sea urchin mass mortality and front formation. Distance on the $x$-axis is relative to the position of the kelp bed/barrens interface. 0 : leading edge of the urchin front, negative values: within kelp bed, and positive values: within barrens

esculenta (5.6 $\left.\mathrm{g} \mathrm{m}^{-2} \mathrm{~d}^{-1}\right)$, based on laboratory measurements of feeding and defecation rates (Table 1). Feces were collected up to $3 \mathrm{~d}$ after defecation in their study, during which time there was significant degradation and loss of fecal material (Sauchyn \& Scheibling 2009b), which could partly explain the lower fecal production rates they obtained. The density of sea urchins at a front is predicted to be most sensitive to changes in survival, growth and movement rate of individuals (Lauzon-Guay et al. 2009). Accordingly, our sensitivity analysis indicates that prediction of fecal production was also most sensitive to variation in these parameters.

As the sea urchin front advances, it ultimately reaches an upper depth limit (which varies both spatially and seasonally) where wave action inhibits destructive grazing (Chapman \& Johnson 1990). At this point, fecal production dramatically decreases and remains low while the system is in the barrens state. Barrens can persist indefinitely, as urchin populations may be sustained by drift algae from intertidal and shallow subtidal habitats, and by microalgal and microbial films, and coralline crusts (Johnson \& Mann 1982). The re-establishment of the alternative, kelpbed state occurs following the sporadic introduction of a pathogenic amoeba that causes widespread mass mortality of sea urchins (Scheibling 1986, Scheibling \& Lauzon-Guay 2010). Survival and growth of the amoeba is temperature dependent (Jellett \& Scheibling 1988) and sea urchins have a thermal refuge below $\sim 20 \mathrm{~m}$, where temperature remains below an infection threshold $\left(10^{\circ} \mathrm{C}\right)$ for paramoebiasis (Brady \& Scheibling 2005). The release from grazing pressure in the shallow subtidal zone enables rapid colonization and re-growth of luxuriant kelp beds within 2 to $3 \mathrm{yr}$ (Scheibling 1986, Johnson \& Mann 1988). Sea urchin populations in shallow water eventually recover through recruitment and immigration from deeper, colder waters. The time required for reformation of the front depends on the linear distance between the surviving sea urchin population and the kelp bed,

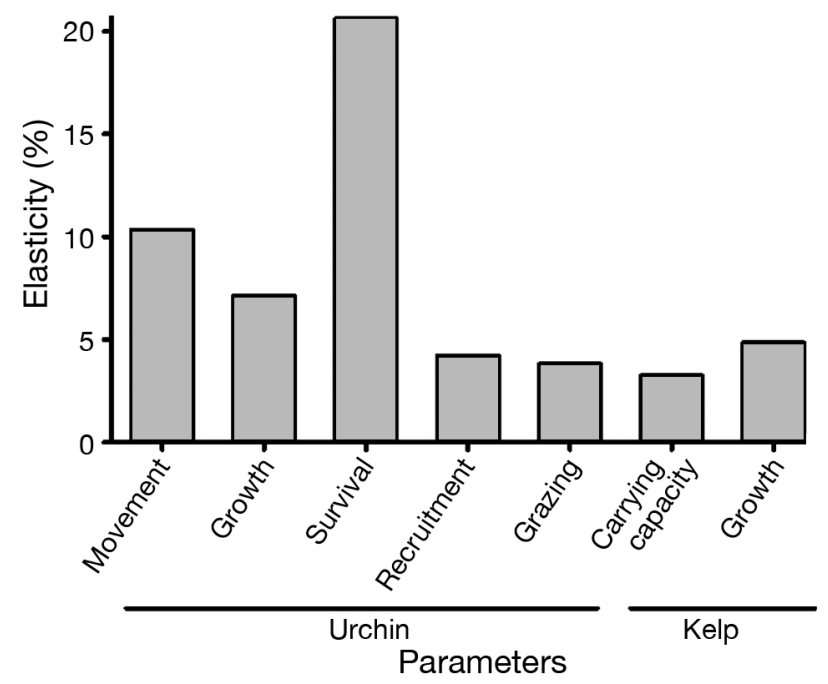

Fig. 4. Elasticity of fecal material production over 10 yr to a $10 \%$ increase in model parameters 
Table 1. Total fecal, carbon, and nitrogen production rates $\left(\mathrm{g} d w t \mathrm{~m}^{-2} \mathrm{~d}^{-1}\right.$ ) of several species of suspension feeding bivalves, gastropod molluscs, planktivorous reef fish, and blackfly larvae in comparison to the sea urchin Strongylocentrotus droebachiensis

\begin{tabular}{|c|c|c|c|c|c|c|}
\hline \multirow[t]{2}{*}{ Species } & \multirow[t]{2}{*}{ Site } & \multirow{2}{*}{$\begin{array}{l}\text { Density } \\
\text { (ind. } \mathrm{m}^{-2} \text { ) }\end{array}$} & \multicolumn{3}{|c|}{ Production $\left(\mathrm{g} \mathrm{m}^{-2} \mathrm{~d}^{-1}\right)$} & \multirow[t]{2}{*}{ Source } \\
\hline & & & Total & Carbon & Nitrogen & \\
\hline \multicolumn{7}{|l|}{ Suspension feeding bivalves } \\
\hline $\begin{array}{l}\text { Adamussium colbecki } \\
\text { (Antarctic scallop) }\end{array}$ & $\begin{array}{l}\text { Terra Nova Bay, Ross Sea, } \\
\text { Antarctica }\end{array}$ & $50-60$ & 0.68 & 0.06 & 0.01 & Chiantore et al. (1998) \\
\hline $\begin{array}{l}\text { Crassostrea virginica } \\
\text { (American oyster) }\end{array}$ & York River, Virginia, USA & & 62 & 14 & 0.77 & $\begin{array}{l}\text { Haven \& } \\
\text { Morales-Alamo (1966) }\end{array}$ \\
\hline $\begin{array}{l}\text { Chlamys farreri } \\
\text { (Zhinkong scallop) }\end{array}$ & Sishili Bay, China & 120 & 9.05 & 0.47 & 0.06 & Zhou et al. (2006) \\
\hline $\begin{array}{l}\text { Mytilus chilensis } \\
\text { (Chilean blue mussel) }\end{array}$ & Quele River Estuary, Chile & $250-300$ & 234 & 14.04 & 0.94 & Jaramillo et al. (1992) \\
\hline $\begin{array}{l}\text { Choromytilus chorus } \\
\text { (giant mussel) }\end{array}$ & Quele River Estuary, Chile & $250-300$ & 271 & 17.34 & 0.81 & Jaramillo et al. (1992) \\
\hline $\begin{array}{l}\text { Mytilus edulis } \\
\text { (blue mussel) }\end{array}$ & Magdalen Islands, Canada & 764 & 16.8 & & & Callier et al. (2009) \\
\hline $\begin{array}{l}\text { Crassostrea gigas } \\
\text { (Pacific oyster) }\end{array}$ & Ofunato Estuary, Japan & 1100 & 270 & $8.1-32.4$ & $1.08-4.05$ & Hayakawa et al. (2001) \\
\hline $\begin{array}{l}\text { Dreissena polymorpha } \\
\text { (zebra mussel) }\end{array}$ & Western Lake Erie, Canada & $1180-1835$ & 26 & & & Klerks et al. (1996) \\
\hline \multicolumn{7}{|l|}{ Gastropod molluscs } \\
\hline $\begin{array}{l}\text { Tegula funebralis } \\
\text { (black turban snail) }\end{array}$ & $\begin{array}{l}\text { Mukkaw Bay, Washington, } \\
\text { USA }\end{array}$ & $412-800$ & $1.18-2.78$ & & & Paine (1971) \\
\hline $\begin{array}{l}\text { Bithynia graeca } \\
\text { (freshwater snail) }\end{array}$ & Lake Kerkini, Greece & 12172 & 0.55 & & & $\begin{array}{l}\text { Eleutheriadis \& Lazari- } \\
\text { dou-Dimitriadou (1996) }\end{array}$ \\
\hline \multicolumn{7}{|l|}{ Planktivorous reef fish } \\
\hline Chromis chromis (damselfish) & $\begin{array}{l}\text { Rocky reef, Bay of Calvi, } \\
\text { France }\end{array}$ & 1 & $\begin{array}{c}0.006- \\
0.015\end{array}$ & $\begin{array}{c}0.0005- \\
0.002\end{array}$ & $\begin{array}{c}0.00005- \\
0.0002\end{array}$ & $\begin{array}{l}\text { Pinnegar \& Polunin } \\
\left(2006^{\mathrm{a}}\right)\end{array}$ \\
\hline \multicolumn{6}{|l|}{ Blackfly larvae } & Bray et al. (1981) \\
\hline Metacnephia lyra, Simulium spp. & Vindel River, northern Sweden & 93000 & $(192$ & 7.5 & & Malmqvist et al. (2001) \\
\hline \multicolumn{6}{|l|}{ Sea urchin } & Wotton et al. (1998) \\
\hline $\begin{array}{l}\text { S. droebachiensis } \\
\text { (green sea urchin) }\end{array}$ & St. Lawrence River, Canada & 150 & 5.6 & & & $\begin{array}{l}\text { Mamelona \& Pelletier } \\
(2005)\end{array}$ \\
\hline $\begin{array}{l}\text { S. droebachiensis } \\
\text { (green sea urchin) }\end{array}$ & Nova Scotia, Canada & 129 & 9.17 & 2.12 & 0.21 & This study \\
\hline${ }^{a}$ Range from fall to spring & & & & & & \\
\hline
\end{tabular}

which is determined largely by the bathymetry of a given site (Lauzon-Guay et al. 2009).

Like many other temperate marine systems, the flux of particulate organic matter along the coast of Nova Scotia also varies seasonally due to changes in urchin grazing rate and absorption efficiency. The grazing rate of Strongylocentrotus droebachiensis is highest in mid-summer, then decreases in late summer and remains low through fall and winter (Meidel \& Scheibling 1998, Scheibling et al. 1999). The absorption efficiency of sea urchins also varies by up to $30 \%$ seasonally and is highest in the fall (Miller \& Mann 1973, Larson et al. 1980). Seasonal changes in grazing rate and absorption efficiency are likely linked to the reproductive cycle of $S$. droebachiensis (Larson et al. 1980, Meidel \& Scheibling 1998). Our model did not account for seasonal variation; we used a yearly-averaged grazing rate and an absorption efficiency calculated for fall. Therefore, our estimates of fecal production are likely to be conservative on an annual basis. These estimates for sea urchins are in the lower range of fecal production rates reported for suspension feeding bivalves, gastropod molluscs, planktivorous reef fish, and blackfly larvae (Table 1).

\section{Feces quality and degradation}

The rate and process of degradation of sea urchin feces also determines their availability as a food source for microbial and metazoan communities. In a previous study at Splitnose Point, we observed an exponential loss of fecal mass after defecation (Eq. 2; Sauchyn \& Scheibling 2009b), which we attributed to the dissolution of organic matter (DOM) and microbial hydrolysis of particulate organic matter (Urban-Rich 1999, Thor et al. 2003). The release of DOM may stimulate microbial activity (Povero et al. 2003, Thor et al. 2003) and provide nutrients for kelp production (Bert- 
ness 1984, Kautsky \& Evans 1987). After egestion, feces produced by urchins grazing the kelp Saccharina longicruris have a relatively high $\mathrm{C}: \mathrm{N}$ ratio $(30.7$; Sauchyn \& Scheibling 2009a), suggesting that they are not easily degraded and are a poor food source for detritivores (Parsons et al. 1984). However, as bacteria use up the labile organic nitrogen within the fecal pellets, they actively take up dissolved inorganic nitrogen from the surrounding seawater (Povero et al. 2003), contributing to the nitrogen content of the feces and decreasing the C:N ratio to 15.9 within 2.5 wk of egestion (Sauchyn \& Scheibling 2009b). In addition to increasing the nitrogen content, microbial activity also results in a relative increase in organic carbon, lipid, and available energy content of the feces during the second week after egestion (Sauchyn \& Scheibling $2009 b)$. The aged feces, with a relatively low C:N ratio and high available energy content, accumulate within the system, where they are likely an important food source for suspension and deposit feeding invertebrates (Newell 1965, Frankenberg \& Smith 1967, Lopez \& Levinton 1987).

The production rate and chemical composition of urchin feces can vary with diet (Mamelona \& Pelletier 2005, Sauchyn \& Scheibling 2009a). This model is based on consumption of Saccharina longicruris, which along with Laminaria digitata is a dominant macroalgal species at Splitnose Point (Lauzon-Guay \& Scheibling 2007). These kelps account for the vast majority of food consumed by the urchin front, although turf algae, epiphytic bryozoa and small benthic invertebrates are also ingested (Knip \& Scheibling 2007).

The rates of microbial degradation in marine environments vary with seasonal changes in temperature (Pomeroy \& Wiebe 2001); however, such variation is unlikely to have a large effect on our model predictions. Sauchyn \& Scheibling (2009b) found no effect of depth on fecal degradation rate when temperature varied from $3.9^{\circ} \mathrm{C}$ at $16 \mathrm{~m}$ to $18.2^{\circ} \mathrm{C}$ at $6 \mathrm{~m}$. In a review of 68 studies, Rivkin et al. (1996) observed only a very weak positive relationship between temperature and microbial activity.

\section{Feces dispersal}

Although we did not include dispersal of the fecal pellets in our model, the fate of this material is an important consideration in our overall understanding of the role of fecal production by sea urchins in organic matter flux and energy flow in this system. Based on the significant wave height observed at our study site, it was estimated that recently defecated fecal pellets $(<24 \mathrm{~h}$ old $)$ produced by a grazing front can travel as bedload to depths of $28 \mathrm{~m}$ in summer and $47 \mathrm{~m}$ in winter, and are deposited there (Sauchyn \& Scheibling 2009a). However, as fecal pellets degrade, they become less dense and are therefore more readily transported to even deeper, less productive waters (Taghon et al. 1984, Sauchyn \& Scheibling 2009a).

\section{CONCLUSION}

Biodeposition by aquatic organisms supplies a large proportion of the energy demand of suspension and deposit feeding communities, affecting their abundance, biomass, and species composition (Wotton et al. 1998, Norkko et al. 2001, Pinnegar \& Polunin 2006, Norling \& Kautsky 2007, 2008). Our mathematical model and previous empirical studies (Sauchyn \& Scheibling 2009a,b) indicate that sea urchin feces represent a significant source of organic matter for benthic populations in rocky subtidal zone and adjacent sedimentary habitats. Fishery surveys estimated that sea urchins destructively grazed $280 \mathrm{~km}$ of kelp beds along the Atlantic coast of Nova Scotia in the mid to late 1990s (Miller \& Nolan 2008). This equals a fecal production rate of $6423 \mathrm{~kg}$ feces $\mathrm{d}^{-1}$ based on our estimate of fecal production after $10 \mathrm{yr}$ of front advance.

Recent changes in the rocky subtidal ecosystem of the Northwest Atlantic underscore the importance of elucidating the role of Strongylocentrotus droebachiensis in detrital food webs. Oceanographic regime shifts and the changing frequency and intensity of the strongest storms are associated with an increase in the frequency of sea urchin mass mortality events along the coast of Nova Scotia over the last 30 yr (Scheibling \& Lauzon-Guay 2010). Storms can also cause extensive defoliation of kelp beds and alter sea urchin grazing activity (Steneck et al. 2002). Invasive species that destroy or displace kelp, such as the epiphytic bryozoan Membranipora membranacea and the green alga Codium fragile, also affect fecal production by sea urchins. Loss of kelp fronds due to outbreaks of $M$. membranacea may accelerate destructive grazing by increasing the ratio of sea urchin density to kelp biomass (Scheibling et al. 1999, Lauzon-Guay \& Scheibling 2007). In addition, changes in the availability and quality of algal food affect the production rate, chemical composition, and dispersal of sea urchin feces (Sauchyn \& Scheibling 2009a). Sea urchins grazing on bryozoanencrusted kelp produce a slightly greater amount of 
higher quality feces that are deposited at shallower depths, while those grazing on $C$. fragile produce a smaller amount of higher quality feces that are deposited at greater depths, compared to sea urchins that consume non-encrusted kelp (Sauchyn \& Scheibling 2009a). The sea urchin dive fishery, which typically targets feeding fronts, can also impact grazing and fecal production rates, especially in areas where sea urchin stocks have seen rapid declines.

In benthic marine ecosystems, variation in the flux of particulate organic matter accounts for a large proportion of the variation in macrobenthic biomass (Grebmeier et al. 1988, Johnson et al. 2007) as suspension and deposit feeders rapidly respond to inputs of this energy source (Whitlatch 1980, Rudnick et al. 1985). Therefore, large-scale changes in the rocky subtidal ecosystem that are associated with natural and anthropogenic stressors and disturbances, are likely to have profound effects on the structure and functioning of adjacent communities that utilize sea urchin feces as a food resource (Pearson \& Rosenberg 1987). This connectivity in the flux of organic matter and energy between different benthic assemblages across a depth gradient remains largely unexplored.

Acknowledgements. This research was supported by a Discovery Grant from the Natural Sciences and Engineering Research Council (NSERC), Canada, to R.E.S. L.K.S. was supported by an NSERC Canada Graduate Scholarship.

\section{LITERATURE CITED}

Bertness MD (1984) Ribbed mussels and the productivity of Spartina alterniflora in a New England salt marsh. Ecology 65:1794-1807

Brady SM, Scheibling RE (2005) Repopulation of the shallow subtidal zone by green sea urchins (Strongylocentrotus droebachiensis) following mass mortality in Nova Scotia, Canada. J Mar Biol Assoc UK 85:1511-1517

> Bray RN, Miller AC, Geesy GG (1981) The fish connection: a trophic link between planktonic and rocky reef communities? Science 214:204-205

Callier MD, Richard M, McKindsey CW, Archambault P, Desrosiers G (2009) Responses of benthic macrofauna and biogeochemical fluxes to various levels of mussel biodeposition: an in situ "benthocosm" experiment. Mar Pollut Bull 58:1544-1553

> Chapman ARO, Johnson CR (1990) Disturbance and organization of macroalgal assemblages in the Northwest Atlantic. Hydrobiologia 192:77-121

> Chiantore M, Cattaneo-Vietti R, Albertelli G, Misic C, Fabiano M (1998) Role of filtering and biodeposition by Adamussium colbecki in circulation of organic matter in Terra Nova Bay (Ross Sea, Antarctica). J Mar Syst 17: 411-424

> Dayton PK, Tegner MJ, Edwards MJ, Riser KL (1998) Sliding baselines, ghosts, and reduced expectations in kelp forest communities. Ecol Appl 8:309-322

Eleutheriadis N, Lazaridou-Dimitriadou M (1996) Nutri- tional budget for the fresh water snail Bithynia graeca (Gastropoda: Bithyniidae). J Molluscan Stud 62:177-184 Fabiano M, Danovaro R, Olivari E, Misic C (1994) Decomposition of fecal matter and somatic tissue of Mytilus galloprovincialis: changes in organic matter composition and microbial succession. Mar Biol 119:375-384

> Frankenberg D, Smith KL (1967) Coprophagy in marine animals. Limnol Oceanogr 12:443-450

> Gaylord B, Reed DC, Washburn L, Raimondi PT (2004) Physical-biological coupling in spore dispersal of kelp forest macroalgae. J Mar Syst 49:19-39

González H, Biddanda B (1990) Microbial transformation of metazoan (Idotea granulosa) feces. Mar Biol 106:285-295

Grebmeier JM, McRoy CP, Feder HM (1988) Pelagic-benthic coupling on the shelf of the northern Bering and Chukchi Seas. I. Food supply source and benthic biomass. Mar Ecol Prog Ser 48:57-67

- Haven DS, Morales-Alamo R (1966) Aspects of biodeposition by oysters and other invertebrate filter feeders. Limnol Oceanogr 11:487-498

Hayakawa Y, Kobayashi M, Izawa M (2001) Sedimentation flux from mariculture of oyster (Crassostrea gigas) in Ofunato Estuary, Japan. J Mar Sci 58:435-444

Jaramillo E, Bertrán C, Bravo A (1992) Mussel biodeposition in an estuary in southern Chile. Mar Ecol Prog Ser 82: 85-94

Jellett JF, Scheibling RE (1988) Effect of temperature and prey availability on growth of Paramoeba invadens in monoxenic culture. Appl Environ Microbiol 54: 1848-1854

Johnson CR, Mann KH (1982) Adaptations of Strongylocentrotus droebachiensis for survival on barren grounds in Nova Scotia. In: Lawrence JM (ed) Proc 4th Int Echinoderm Conf, Tampa Bay. Balkema, Rotterdam, p 277-283

Johnson CR, Mann KH (1988) Diversity, patterns of adaptation, and stability of Nova Scotian kelp beds. Ecol Monogr 58:129-154

> Johnson NA, Campbell JW, Moore TS, Rex MA, Etter RJ, McClain CR, Dowell MD (2007) The relationship between standing stock biomass of deep-sea macrobenthos and surface deposition in the western North Atlantic. Deep-Sea Res I 54:1350-1360

> Kautsky N, Evans S (1987) Role of biodeposition by Mytilus edulis in the circulation of matter and nutrients in a Baltic coastal ecosystem. Mar Ecol Prog Ser 38:201-212

Klerks PL, Fraleigh PC, Lawniczak JE (1996) Effects of zebra mussels (Dreissena polymorpha) on seston levels and sediment deposition in western Lake Erie. Can J Fish Aquat Sci 53:2284-2291

> Knip D, Scheibling RE (2007) Invertebrate fauna associated with kelp enhances reproductive output of the green sea urchin Strongylocentrotus droebachiensis. J Exp Mar Biol Ecol 351:150-159

> Larson BR, Vadas RL, Keser M (1980) Feeding and nutritional ecology of the sea urchin Strongylocentrotus droebachiensis in Maine, USA. Mar Biol 59:49-62

> Lauzon-Guay JS, Scheibling RE (2007) Behaviour of sea urchin Strongylocentrotus droebachiensis grazing fronts: food-mediated aggregation and density-dependent facilitation. Mar Ecol Prog Ser 329:191-204

> Lauzon-Guay JS, Scheibling RE, Barbeau MA (2008) Formation and propagation of feeding fronts in benthic marine invertebrates: a modeling approach. Ecology 89: 3150-3162

> Lauzon-Guay JS, Scheibling RE, Barbeau MA (2009) Modelling phase shifts in a rocky subtidal ecosystem. Mar Ecol Prog Ser 375:25-39 
Lawrence JM (1975) On the relationships between marine plants and sea urchins. Oceanogr Mar Biol Annu Rev 13: 213-286

Lopez GR, Levinton JS (1987) Ecology of deposit-feeding animals in marine sediments. Q Rev Biol 62:235-260

Malmqvist B, Wotton RS, Zhang Y (2001) Suspension feeders transform massive amounts of seston in large northern rivers. Oikos 92:35-43

Mamelona J, Pelletier E (2005) Green urchin as a significant source of fecal particulate organic matter within nearshore benthic ecosystems. J Exp Mar Biol Ecol 314:163-174

Mann KH (2000) Ecology of coastal waters, with implications for management, Vol 2. Blackwell, Oxford

Meidel SK, Scheibling RE (1998) Size and age structure of the sea urchin Strongylocentrotus droebachiensis in different habitats. In: Mooi R, Telford M (eds) Proc 9th Echinoderm Conf, San Francisco. Balkema, Rotterdam, p 737-742

Miller RJ, Mann KH (1973) Ecological energetics of the seaweed zone in a marine bay on the Atlantic coast of Canada. III. Energy transformations by sea urchins. Mar Biol 18:99-114

Miller RJ, Nolan SC (2000) Management of the Nova Scotia sea urchin fishery: a nearly successful habitat based management regime. Fisheries and Oceans Science, Canadian Stock Assessment Secretariat, Ottawa

Miller RJ, Nolan SC (2008) Management methods for a sea urchin dive fishery with individual fishing zones. J Shellfish Res 27:929-938

Neubert MG, Caswell H (2000) Demography and dispersal: calculation and sensitivity analysis of invasion speed for structured populations. Ecology 81:1613-1628

Newell R (1965) The role of detritus in the nutrition of two marine deposit feeders, the prosobranch Hydrobia ulvae and the bivalve Macoma balthica. Proc Zool Soc Lond 144:25-45

Norkko A, Hewitt JE, Thrush SF, Funnell GA (2001) Benthic-pelagic coupling and suspension-feeding bivalves: linking site-specific sediment flux and biodeposition to benthic community structure. Limnol Oceanogr 46:2067-2072

> Norling P, Kautsky N (2007) Structural and functional effects of Mytilus edulis on diversity of associated species and ecosystem functioning. Mar Ecol Prog Ser 351:163-175

Norling P, Kautsky N (2008) Patches of the mussel Mytilus sp. are islands of high biodiversity in subtidal sediment habitats in the Baltic Sea. Aquat Biol 4:75-87

> Paine RT (1971) Energy flow in a natural population of the herbivorous gastropod Tegula funebralis. Limnol Oceanogr 16:86-98

Parsons TR, Takahashi M, Hargrave B (1984) Biological oceanographic processes, 2nd edn. Pergamon Press, Oxford

Pearson TH, Rosenberg R (1987) Feast and famine: structuring factors in marine benthic communities. In: Gee JHR, Giller PS (eds) Organization of communities, past and present. Blackwell, Oxford, p 373-395

> Pinnegar JK, Polunin NVC (2006) Planktivorous damselfish support significant nitrogen and phosphorus fluxes to Mediterranean reefs. Mar Biol 148:1089-1099

Pomeroy LR, Wiebe WJ (2001) Temperature and substrates as interactive limiting factors for marine heterotrophic bacteria. Aquat Microb Ecol 23:187-204

Povero P, Misic C, Ossola C, Castellano M, Fabiano M (2003)

Editorial responsibility: Matthias Seaman,

Oldendorf/Luhe, Germany
The trophic role and ecological implications of oval faecal pellets in Terra Nova Bay (Ross Sea). Polar Biol 26:302-310

Rivkin RB, Anderson MR, Lajzerowicz C (1996) Microbial processes in cold oceans. 1. Relationship between temperature and bacterial growth rate. Aquat Microb Ecol 10:243-254

Rudnick DT, Elmgren R, Frithsen JB (1985) Meiofaunal prominence and benthic seasonality in a coastal marine ecosystem. Oecologia 67:157-168

Sauchyn LK, Scheibling RE (2009a) Fecal production by sea urchins in native and invaded algal beds. Mar Ecol Prog Ser 396:35-48

Sauchyn LK, Scheibling RE (2009b) Degradation of sea urchin feces in a rocky subtidal ecosystem: implications for nutrient cycling and energy flow. Aquat Biol 6:99-108

Scheibling RE (1986) Increased macroalgal abundance following mass mortalities of sea urchins (Strongylocentrotus droebachiensis) along the Atlantic coast of Nova Scotia. Oecologia 68:186-198

Scheibling RE, Hatcher BG (2007) The ecology of Strongylocentrotus droebachiensis. In: Lawrence JM (ed) Edible sea urchins: biology and ecology. Elsevier, Amsterdam, p 353-392

Scheibling RE, Lauzon-Guay JS (2010) Killer storms: North Atlantic hurricanes and disease outbreaks in sea urchins. Limnol Oceanogr 55:2331-2338

Scheibling RE, Hennigar AW, Balch T (1999) Destructive grazing, epiphytism, and disease: the dynamics of sea urchin-kelp interactions in Nova Scotia. Can J Fish Aquat Sci 56:2300-2314

Steneck RS, Graham MH, Bourque BJ, Corbett D, Erlandson JM, Estes JA, Tegner MJ (2002) Kelp forest ecosystems: biodiversity, stability, resilience and future. Environ Conserv 29:436-459

> Taghon GL, Nowell ARM, Jumars PA (1984) Transport and breakdown of fecal pellets: biological and sedimentological consequences. Limnol Oceanogr 29:64-72

Thor P, Dam HG, Rogers DR (2003) Fate of organic carbon released from decomposing copepod fecal pellets in relation to bacterial production and ectoenzymatic activity. Aquat Microb Ecol 33:279-288

Turchin P (2003) Complex population dynamics: a theoretical/ empirical synthesis. Princeton University Press, Princeton, NJ

Urban-Rich J (1999) Release of dissolved organic carbon from copepod fecal pellets in the Greenland Sea. J Exp Mar Biol Ecol 232:107-124

Uthicke S, Schaffelke B, Byrne M (2009) A boom-bust phylum? Ecological and evolutionary consequences of density variations in echinoderms. Ecol Monogr 79:3-24

Whitlatch RB (1980) Patterns of resource utilization and coexistence in marine intertidal deposit-feeding communities. J Mar Res 38:743-765

Wotton RS, Malmqvist B (2001) Feces in aquatic ecosystems. Bioscience 51:537-544

> Wotton RS, Malmqvist B, Muotka R, Larsson K (1998) Fecal pellets from a dense aggregation of suspension-feeders in a stream: an example of ecosystem engineering. Limnol Oceanogr 43:719-725

Zhou Y, Yang H, Zhang T, Liu S and others (2006) Influence of filtering and biodeposition by the cultured scallop Chlamys farreri on benthic-pelagic coupling in a eutrophic bay in China. Mar Ecol Prog Ser 317:127-141

Submitted: November 1, 2010; Accepted: June 8, 2011

Proofs received from author(s): September 19, 2011 